\title{
"Win-win" agricultural investment projects put to the test: the case of the IDSP project as promoted by the World Bank in Zambia
}

\section{Clémentine Rémy ${ }^{1}$ (D) Hubert Cochet $^{2}$}

Received: 5 February 2019 / Accepted: 30 May 2020/ Published online: 5 August 2020

(C) INRAE and Springer-Verlag France SAS, part of Springer Nature 2020

\begin{abstract}
For fear of being accused of land grabbing, investors, the governments of host countries and international donors have sought to develop jointly capitalist farming and family farming by seeking synergies from "win-win" projects. The Irrigation Development Support Project (IDSP), established under the supervision of the Zambian government and financed by the World Bank, constitutes one of the prototypes of this new generation of projects. The aim of this article is to examine the conception and implementation of this project and to question its likely impact. By relying on the professional experience of one of the authors of this article on three of the sites of the project, on the critical reading of the project's documents put at our disposal and, finally, on qualitative surveys carried out in 2017, 2018 and 2019, we highlight the contradictions inherent to the project, implementation difficulties and the foreseeable impact of the project on family farming, as well as in terms of national benefit.
\end{abstract}

Keywords Family farming · Capitalist agriculture $\cdot$ Development model $\cdot$ Comparative agriculture $\cdot$ Irrigation $\cdot$ Zambia

\section{Introduction}

Private investments in the agricultural sector in Sub-Saharan Africa have increased since the food price crisis of 2008. Reinforced by a reduction in international aid to agricultural development, this phenomenon is, in many cases, expressed as land being

Clémentine Rémy

cle.remy@gmail.com

1 Comparative Agriculture and Agricultural Development Research Unit, Prodig Joint Research Unit, AgroParisTech|, Paris, France

2 Comparative Agriculture and Agricultural Development Research Unit, Prodig Joint Research Unit, AgroParisTech-Université Paris-Saclay, Paris, France 
taken over and cultivated by capitalist farms. Criticised at first by many international actors, then controlled by the Voluntary Guidelines on the Responsible Governance of Tenure of Land, Fisheries and Forests in the Context of National Food Security (CFS, 2012), today this trend is supported by international donors and governments that supposedly intend to tap private funds, to create synergies from the activity of capitalist farms considered to be more performant and, as such, to develop family farming. The importance of the latter has in fact been reaffirmed, on the occasion of the international year of family farming in 2014, to take up the challenges of food security, employment and the fight against poverty.

The Irrigation Development Support Project (IDSP) ${ }^{1}$, established under the supervision of the Zambian government and financed by the World Bank, is presented by the donor as the prototype - or model - of a new generation of investment projects in Public-Private Partnerships (PPP) that are to benefit capitalist farming businesses and at the same time family farmers on whose lands dams and irrigated areas are being established. As future beneficiaries of a significant part of the land being irrigated, national or foreign investors are invited to take part in investment finance, in managing irrigation infrastructure (maintaining future irrigated areas, collecting taxes from other beneficiaries, etc.), in transferring technology and in re-structuring the agri-food systems. At the same time, farming families, whose village land is partly mobilised for the project, will theoretically each receive, ready for use, a plot of land equipped with irrigation infrastructure, facilitated access to inputs and equipment needed for its development, and the possibility of being part of one or several networks activated by the capitalist farming businesses benefiting from the project. As such, investors and family farmers are supposed to be joint beneficiaries of the project, thereby illustrating the "win-win" nature of this new development model, while the participation of capitalist firms in financing the project must compensate for scarce government finance and reduce the public debt.

The objective of this article is to examine the design and implementation arrangements of the project and to scrutinize its likely impact. By relying, firstly on the professional experience of one of the authors of this article, who was mobilised between 2012 and 2014 for the Community Participation and Capacity Building (CP\&CB) component for three of the sites of the IDSP, secondly on a new critical reading of the project documents, and thirdly on qualitative surveys carried out in 2017 , 2018 and 2019 at the site of Mwomboshi, we will try to reveal the contradictions inherent to the project, the implementation difficulties, the foreseeable impact of the project on family farming and the economic benefit to Zambia.

After summarising the context and current debates on these issues ("Context and current debates" section), we will present the methodological components that inspired this article ("Methodological components" section). The general principles of the project, as understood from reading the project documents, informed by almost two years of implementation experience and focussed to for scientific analysis, will then be tackled ("The irrigation development support project: general principles" section). We will then examine part of the actual implementation of the project (particularly the investment phase and the displacement and compensation of affected

\footnotetext{
${ }^{1}$ The main project documents used are as follows: World Bank (2011); IDSP/MAL/WB (2012, 2015a, 2015b).
} 
populations) in one of the Zambian rural areas where the project has been ongoing since 2012 ("From project documents to concrete implementation: the case of the site of Mwomboshi" section). Finally, we will show the first results of our impact assessment (“Complementarity or competition: towards a win-win farming model?" section). The contradictions inherent to the a priori concept of this type of project will be highlighted, as well as the predicted consequences, from the viewpoint of the given objectives, on family agriculture.

\section{Context and current debates}

The large-scale movement for the acquisition or control of agricultural land by public or private actors is not new (Borras et al., 2012). In Sub-Saharan Africa, it was in full expansion well before the financial crisis of 2008 (Cotula et al., 2010). For all that, the surge in agricultural prices during 2007-2008 gave it an unprecedented scale. It was, from then on, a large movement led by private investors that saw in it an opportunity to make considerable profits while diversifying their portfolios.

These projects, which concern mostly developing countries, have often been introduced by their promoters as follows (Cochet and Merlet 2011; Cochet 2017):

(1) It is imperative to increase significantly agricultural (and energy) production on a global scale, so as to face the rising needs of humanity (population increase, progressive generalisation of the consumer model of the countries of the North, predictable depletion of fossil fuels) (e.g. World Bank 2007, CAS 2010).

(2) There is supposedly one billion hectares of good quality land that has not yet been cultivated and is not covered by forests, and which is "available", of which $80 \%$ is in Sub-Saharan Africa and Latin America (Fisher et al., 2002).

(3) The productivity of the agricultural sector in these countries is supposedly stagnating, due to the States' or the farmers' lack of capacity to invest in modern technologies (CAS, 2010; FAO, 2009; UNCTAD, 2009). For States and international institutions (FAO, ONU), resorting to private and/or foreign investments would constitute a solution to the problem of financing agriculture, in a context where public aid to development has been decreasing (Deininger et al. 2011, Anseeuw et al., 2016; Blein et al. 2017).

(4) Subject to having comprehensive, inexpensive and, in the long term, guaranteed access to land, foreign investors propose to bring in the capital required for increasing agricultural production. That is why targeted countries - or host countries - were highly encouraged, during the 1990 s and 2000 s, to ensure that their legislation was adapted with a view to favouring the massive inflow of foreign capital in the agricultural sector (Daniel and Mittal 2010).

(5) As regards employment, this beneficial injection of capital in the agricultural sector of developing countries would be a powerful lever to create direct employment in agriculture as well as raise incomes (salaries, rent paid to eligible parties) based on a "win-win" partnership (CAS, 2010; Cotula et al., 2010; Deininger and Byerlee 2012; FAO, 2009). 
This movement to take over large agricultural areas gave rise to many criticisms and critical publications emanating from civil society organisations (farmers' organisations, NGOs, etc.), as well as international institutions (FAO, World Bank, etc.). These publications highlight the absence of consent by the populations' concerned, the lack of transparency of the land transactions, the potential eviction of the rural people occupying the land targeted (and therefore the massive loss of related jobs) but also the risks incurred concerning food security and the environment (Cochet 2014, De Schutter 2009, "Technical Committee on Land and Development" 2010; Songwe and Deininger 2009, Cotula et al. 2010, Borras and Franco 2010, Deininger et al. 2011; Fairhead et al., 2012, Pallière and Cochet 2018) ${ }^{2}$. The signing of the Voluntary Guidelines on the Responsible Governance of Tenure of Land, Fisheries and Forests in the Context of National Food Security (CFS, 2012) in Rome, in 2012, marks a global consensus on the need to reduce these risks. Other authors insist, rather, on the deep historical as well as political causes of the phenomenon and encourage wider questioning, regarding the development models being promoted in particular. They point out the limitations of these approaches in terms of governance (Zoomer 2013).

These major investment projects have also reopened the debate on capitalist farming versus family farming ${ }^{3}$, at the very moment when the international year of family farming (2014) was being prepared, under the aegis of the UN. These projects are mostly characterized by large production units, equipped with powerful equipment (but also calling on an abundant labour force in some production systems or agricultural operations) and specialised in one or few crops, instead of small or medium family farms that are less capital intensive but often more diversified. Which of these two forms of agriculture is better suited to ensure quality food in the long term for an increasingly growing population whose eating habits change? Which one will be able to create jobs and ensure a decent income to those who devote themselves to it? And which performance criteria will be used to compare these different forms of agriculture? (Deininger and Byerlee, 2012, Losch and Fréguin-Gresh, 2013, Cochet 2015b).

The development process of capitalist farming has also affected Zambia, where the land presented by the World Bank (Deininger and Byerlee 2012) as being "available"4 is vast. Capitalist forms of farming have existed there since the colonial period, within designated farm blocks of several thousands of hectares (Laske 2014, Chu 2012, Chu 2013, Here 2013). This type of capitalist farming was later expanded from the 1990s onwards through the settlement of South African or Zimbabwean farmers and was stimulated again since the end of the 2000s by the international context (Chu 2013; Chu et al. 2015: Nolte and Subakanya 2016). Accompanying this process, the liberalisation of the Zambian economy and the drafting of the Land Act of 1995 created conditions conducive to the acquisition and cultivation of land by capitalist farms (Nolte 2013). Today, Zambia is one of 20 countries most concerned by agricultural investments involving large-scale land acquisition, as mentioned in the data bank of the Land

\footnotetext{
${ }^{2}$ On the diversity of forms of capitalist farming development, see also Purseigle et al. (2017).

${ }^{3} \mathrm{We}$ define entrepreneurial or capitalist farming as a type of agriculture characterised by a "separation between labour and capital", where the owner of the capital invested in the productive process, takes little or no part in the "labour carried out by a labour force which is salaried or paid by the piece", and we define family farming as a type of agriculture for which "most or all the labour is carried out by the farmer and his family who own the working capital" (Cochet 2015b).

${ }^{4}$ Such land availability remains controversial (Here 2013).
} 
Matrix, (Nolte et al. 2016) in a context where the farming population, which practices mainly manual and food-producing family farming centred on maize production (which has been supported by the State over different periods since the colonial era), represented $61 \%$ of households nationally in 2018 (Ministry of Fisheries and Livestock, CSO (Central Statistic Office), 2019, CSO (Central Statistical Office), 2014).

For fear of being accused of land grabbing, investors, the governments of hosting countries and international donors have sought a way to bring together these two farming "models", by attempting to forge a link between the two in the form of "win-win" projects. The Irrigation Development Support Project (IDSP), set up under the supervision of the Zambian government and financed by the World Bank, constitutes one of the prototypes of this new generation of projects-Public-Private Partnerships (PPP) - that are to benefit private investors and, at the same time, the villagers on whose lands dams and irrigated areas are being established ${ }^{5}$.

\section{Methodological components}

Taking a critical, contextualised, and, at the same time, reality-bound look at a situation which is changing and very far from being stabilised is not an easy task. How to distinguish what relates to the conception and management of the project, from what is imposed by local biophysical as well as socioeconomic constraints on its concrete implementation? How to make allowances between the massive disruptions (although temporary) linked to the investment phase and the perennial disruptions that permanently modify the living conditions of impacted populations? Avoiding hasty judgements and cut-and-dried diagnostics, as well as the many biases often found in the literature on agricultural projects involving large-scale land deals (Oya 2013), demands that we re-examine localised and contextualised situations and that these are analysed as closely as possible to "field conditions".

To identify project impact requires a comparison of the "with-project" scenario with a reference scenario: this is the basic principle on which any assessment must be based. It makes it possible to reveal a differential between the "with-project" scenario and the situation that would have prevailed if the project had not come into being (the "withoutproject" scenario), this differential being the sole rigorous measure of the transformations attributable to the project, i.e. of its real impact (Baker 2000; Bridier et al. 1980; Dufumier, 1996; Gittinger 1985). In order to assess the projected impact of the IDSP, the "with-project" scenario can be built partly from hypotheses formulated on the basis of the project documents and monitoring of the project's implementation. Setting up a large size capitalist farm by an investor and its business plan is part of the "withproject" scenario. But the main impact expected from the project is the leverage on family farming development, from the viewpoint of what the family farming situation would be like if the project had not been set up ("without-project" scenario). It is this comparison that turns out to be the most difficult to establish. To this end, scenarios of

\footnotetext{
${ }^{5}$ Another example of these projects is given by the PDIDAS Project in Senegal (Comite technique Foncier \& Développement 2017).
} 
evolution "with project" and "without project" can be built for each category of farmer (Delarue and Cochet 2013, Rangé and Cochet 2018, Pallière and Cochet 2018), from a prior diagnostic of the agrarian system, which includes the identification and characterisation of current production systems. ${ }^{6}$

The stage of our research does not yet make it possible to reveal the projected impact of such a project in terms of differential with/without project. In a first phase, the results of which are presented here, our approach, which is pragmatic and rooted in the field, consists of combining different sources of data and putting them into perspective to give a provisional review of this type of project. The primary source of first-hand information was given to us as a result of the participation, between 2012 and 2014, of one of the authors of this article in the preparatory phase of the IDSP implementation on three of the project sites and on the Community Participation and Capacity Building $(\mathrm{CP} \& \mathrm{CB})$ component in particular. The second source of data mobilized is that offered by the various project documents (World Bank 2011, IDSP/MAL/WB 2012, IDSP/MAL/WB 2015a, IDSP/MAL/WB 2015b), which we have re-read in detail. This enabled us to highlight the philosophy and general principles of the intervention and sometimes its internal contradictions. A third source of essentially qualitative data comes from field surveys conducted by us on one of the three IDSP sites, that of Mwomboshi, during the investment phase of the project, in 2017, 2018 and 2019.

In the approach we adopted, the collection of data and the analysis began with the professional experience of one of the authors, i.e. almost two years of immersion within the project and interaction with the stakeholders: family farmers during bi-quarterly visits on the three IDSP sites and members of the Zambian Ministry of Agriculture, the World Bank and various consulting firms contracted by the Zambian government to conduct studies prior to the investment phase, during monthly co-ordination meetings. Her involvement in informing and consulting with family farmers (CP\&CB component) required that the principles and terms of the project be assimilated as well as discussed. This enabled the authors to enter into dialogue and reinforce each other's operational and scientific positions, with the operational viewpoint bringing in concrete and already critical elements which from a scientific viewpoint could then be reinterpreted and objectivised. Monitoring the implementation of the project since 2012 made it possible to put into perspective the principles as they are described in the project documents, as they were defended or discussed during the preparatory phase and as they have been implemented during the still ongoing investment phase. The elements presented in this article are the result of this comparison between the operational and scientific viewpoints.

For this article, we reinterpret a posteriori with the assistance of the data collected on one of the IDSP sites (Mwomboshi) and the public documents of that project, particularly the Project Appraisal Document (PAD) which was drafted before implementing the project and the Resettlement Action Plan (RAP) which was drafted and revised over 4 years, from 2013 to 2017 .

\footnotetext{
${ }^{6}$ On the concept of the agrarian system and the methods used to identify and characterise production systems, we refer the reader to the approach used in comparative agriculture (Cochet and Devienne 2006; Cochet 2012; Cochet 2015a).
} 


\section{The irrigation development support project: general principles}

The IDSP, for the sum of two hundred and one million dollars, is financed by the World Bank and is implemented by the Zambian Ministry of Agriculture in three rural areas of Zambia. As introduced during the IDSP kick-off meeting in November 2012, these sites were chosen by the Zambian Ministry of Agriculture and the World Bank to constitute showcase tests for IDSP modalities and to serve as models for the development of other rural regions. During the preparatory phase, it was possible to observe different agrarian situations (in terms of pedoclimatic conditions, land access methods, farming practices, etc.), all of these being nonetheless characterised by almost exclusively manual family farming. The crops are mainly rain-fed and are sometimes combined with wetland, flood plain or bucket-irrigated vegetable crops and a few heads of livestock (mostly goats and sometimes cattle). Four other areas have been pre-identified for the second potential phase of the project (Fig. 2).

The IDSP is an irrigation development project that provides for the construction and management of irrigated areas, within the framework of a Public-Private Partnership (PPP), with the given objective of increasing agricultural production and developing family farming. It provides for the development of almost 3000 ha spread over the three targeted sites, of which $60 \%$ are intended for external investors (World Bank 2011; IDSP/MAL/WB 2015a; IDSP/MAL/WB 2015b). Approved in April 2011, planned for 5 years and, to our knowledge, extended by three, the implementation of the IDSP began in November 2012 (Fig. 1). It was initially supposed to extend from the feasibility studies to the first year of cultivation of the irrigated areas including, among other elements, construction and the negotiation of the contracts between family farmers and capitalist farmers (IDSP/MAL/WB 2012).

The interpretation of the general principles of the IDSP is briefly exposed in the following paragraphs. It results from the comparative reading, dissociated in time, of the texts of the project and the monitoring of its implementation since 2012 (cf. "Methodological components" section); it reflects the "spirit" of the project as discussed and affirmed during the preparatory phase of its implementation and as it is found in the project documents.

\section{Making land available for a capitalist farming company in exchange for pressurized water and services to "develop" family farming}

The IDSP relies on the premise that the cost of irrigation cannot be paid for by family farmers and that the latter, to benefit from it, must cede part of their land to an investor that is likely to take care, in return, of part of the operational, maintenance and management costs of the irrigated areas (or even the reimbursement of part of the investment realised by the State). The Zambian government seeks, in this way, to create attractive conditions in order to attract investors, with the latter being invited, moreover, to facilitate access to markets and inputs, and to provide technical support to family farmers. The IDSP comes up as a "give and take" and, at the same time, a "win-win" project which is engaging for the State, family farmers and capitalist farming companies (IDSP/MAL/WB 2015a; IDSP/MAL/WB 2015b). The IDSP is presented as an innovative pilot project that must create a context conducive to investment by capitalist farming companies. 


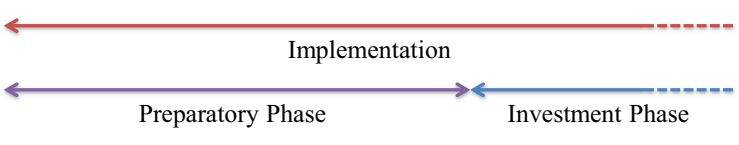

Project

Progress

$\begin{array}{cccc}\text { Validation of } & 0 & 0 & 0 \\ \text { the PAD } & \text { First } & \text { Validation of } & \text { Inauguration of } \\ \text { (IDSP/MAL } & \text { submission of } & \text { the RAP of } & \text { the dam of } \\ \text { /WB 2012) } & \text { the RAP } & \text { Mwomboshi } & \text { Mwomboshi } \\ & & \text { (IDSP/MAL/ } & \\ & \text { WB 2015a) }\end{array}$

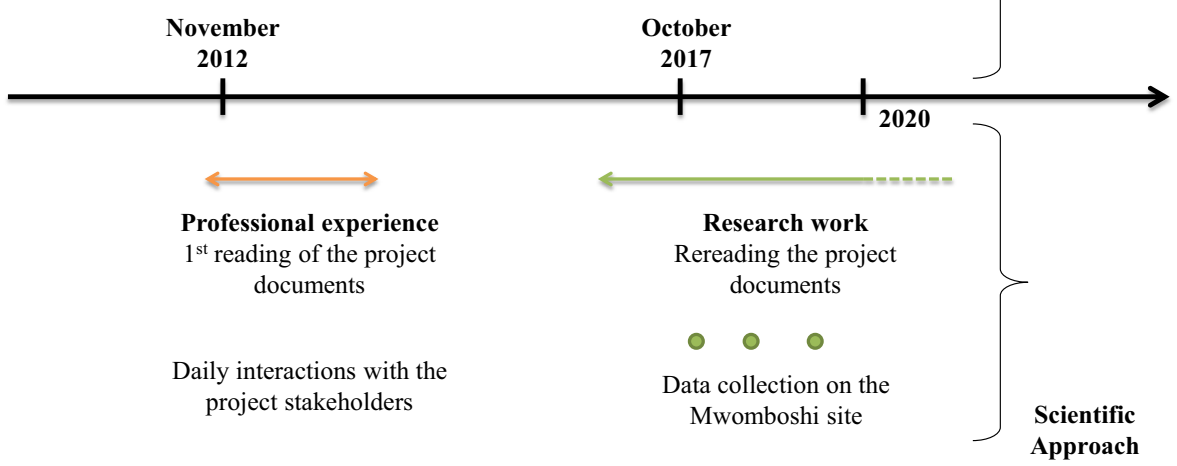

Fig. 1 Project development on the site of Mwomboshi and development of a scientific approach. Source: authors

\section{Three development "levels" predefined according to the alleged capacity of farmers to invest and market their productions}

The promoters of the project plan to develop and distribute irrigable lands, according to a normative classification of the farmers into three distinct categories, "small" and "emergent" for family farmers and "commercial" for capitalist farming companies. As such, they create levels of development, putting into place conditions for irrigated cultivation (equipment and accessible surface area) which, they suppose, are adapted to the farmers' means, their "capacity" to invest and to market their production (IDSP/MAL/WB 2015a; IDSP/MAL/WB 2015b).

"Small" farmers will have access to the so-called "tier 1" or level 1 land made up of plots of less than 1 ha, equipped with hosepipes connected to pressurised water for vegetable crop and maize production, partly for sale and partly for home consumption. Farmers identified as "emergent", which is the "intermediary" category between "small" and "commercial" farming, will be selected to cultivate, individually or in groups, so-called "Tier 2" land which can be irrigated using sprinklers or small pivot systems ${ }^{7}$, under contract with the capitalist farming companies. The latter will then have access to so-called "tier 3" land that can be irrigated using pivot systems, for

\footnotetext{
${ }^{7}$ To our knowledge, "emergent" farmers will be selected on the basis of business plans. The project documents do not specify or quantify the criteria that will be used in defining farmers and qualifying them for plot allocation in "tier 2".
} 
wheat and soya production (or even banana or coffee, depending on the rural areas), intended for the international or national market (IDSP/MAL/WB 2012).

Through this project, the Zambian government and the World Bank intend to create synergy by making family farmers benefit from the "ability" of the capitalist farmer to invest, produce in large quantity, market and clear a profit, an ability which family farmers would be lacking.

An important ethos of IDSP is that smallholders, emergent farmers and commercial farmers, with their complementary resources of land, labour, capital and business ability should co-operate and so enhance the irrigation project. (IDSP/MAL/WB 2015a)

\section{Terms regulating the conditions for accessing and sharing land and irrigation water}

\section{Land consolidation and conversion to state land, lease and Community Land Trust}

According to the documents, the status of the land that will be mobilised within the framework of the project (on which infrastructure will be built, the land that will be made irrigable, where displaced households will be resettled or even that which will be flooded when a dam is planned) will change from customary land managed by customary chiefs to State land. This principle is presented within the framework of the project as a necessary precondition to investment by the State. Of note is the fact that in the Zambian context, according to the Land Act of 1995, only State-owned land can be leased out to investors (Nolte 2013): it is therefore necessary to convert customary land so that it can be reallocated. It is then expected that a Community Land Trust be established, that it accesses irrigable land though a 99-year lease from the State, so as to manage the land in the name of all family farmers. The land is then to be sub-let to the capitalist farming company as well as to "emergent" family farmers (who are exploiting "tier 2"). The land will be allocated (free of charge and in perpetuity) to "small" family farmers (who are exploiting "tier 1") so as to "reproduce" a customary land access method, which is a novelty from the IDSP. This allocation, however, will be associated with a "duty" to irrigate and pay for the charges associated with farming the land (irrigation tax in particular), as is usually the case in this type of project (Technical Committee on Land Tenure and Development 2017). Finally, one of the major principles that came up during the preparatory phase of the IDSP, and which is also mentioned in the project documents, is that all the families of the villages affected by the project (and not only those that lost land) qualify for a plot allocation in "tier 1" and as such "benefit" from the project without being necessarily directly impacted. The concept of land compensation methods relies partly on this principle (cf. under "Compensation presented as exemplary and carried out before starting the works" section).

\section{Investment and water access methods}

Except for the on-farm irrigation equipment, which should be provided by the beneficiaries, it is expected that the main irrigation infrastructure (dam, pumping station, 
reservoir, pipe network, etc.) remains in the public domain. The infrastructure varies from one site to another depending on the natural conditions (river, topography, etc.), and on the planned development (distance from the irrigated area to the water source for example): while irrigation water will be pumped directly from the Kafue and Zambezi Rivers for two of the three sites where the investment phase of the IDSP is ongoing, a dam (cf. under "The area of Mwomboshi: concrete elements and distinctive characteristics" section) has been built on the site of Mwomboshi, which we are examining below.

A private company will be requested by the State to manage the irrigated areas, i.e. to ensure their operation and maintenance, as well as to collect taxes from users ${ }^{8}$. The company managing the irrigated area (contractor or operator in the project documents) can also be the one cultivating "tier 3". In this case, we note that the capitalist farming company will be in charge of water release and rotation and therefore of the methods used to share water between farmers, including during periods of potential competition for water resources, for example, in case of prolonged drought.

\section{Compensation presented as exemplary and carried out before starting the works}

Compensatory measures meet the expectations of international donors within the framework of this type of project, which involve the displacement of populations and the acquisition of land. The definition of these measures is in accordance with the safeguard policies of the World Bank and with Operational Policy 4.12 in particular, concerning the "Involuntary Resettlement of People" (World Bank 2013). This, as mentioned in the RAP, contributes to the image given to the IDSP as an exemplary project and favours its acceptance whether locally, nationally or internationally. As frequently pointed out during the coordination meetings of the preparatory phase by the World Bank representatives, population displacements must not begin before resettlement conditions are in place (houses must be already built). The situation of displaced people must be equivalent or better than their previous situation. The importance of the budget allocated to defining and implementing compensatory methods highlights that fact that the IDSP must be irreproachable and serve as showcase.

"The guiding principle throughout will be that where people are negatively affected by project activities, they should be no worse off, if not better off, after the resettlement has taken place than they were before." (IDSP/MAL/WB 2012)

The compensatory methods concern the displacement and resettlement of farming families whose housing is situated on future irrigable land. On the other hand, there is no provision to compensate farming families ceding their land to the project, because

\footnotetext{
${ }_{8}^{8}$ The total amount for the rent and water charges (including the management and maintenance service carried out by the capitalist farming company), as well as how much of the water charges the capitalist farming company will be paying for, are not specified in the publicised project documents. Nonetheless, proposals were made by one of the consulting firms contracted by the Zambian Ministry of Agriculture during the preparatory phase of the IDSP and were presented to the family farmers of the three sites targeted by the project, during various information meetings in 2014.
} 
it is considered that the family farmers losing their land will be compensated by the allocation of other rain-fed plots, by the village headman ${ }^{9}$, as early as the construction phase of the irrigated area starts, and plots to which irrigable land will be added, once the irrigated area is operational. It is planned indeed that rain-fed land will be redistributed between the family farmers of the concerned villages by the project and that everyone will benefit from an irrigable plot (cf. "Land consolidation and conversion to state land, lease and community land trust" section). This way, the project documents suggest that family farmers (those who lost their land as well as those who gave rain-fed land to the former) will not sustain a loss of income during the construction period of the irrigable area (compared to income that would have been cleared without project) or that they will be compensated a posteriori by more income made possible through irrigated cultivation. A subsidy is nonetheless provided for to finance the clearing of the newly allocated rain-fed land.

"In principle, there should be no temporary loss of household income from displacement, as the Chief in the project area has agreed that more than sufficient land is available for interim replacement. Additional interim rain-fed land will therefore be available and be allocated until the irrigation scheme is operational to ensure that PAPs will not suffer loss of income during this interim phase." (IDSP/MAL/WB 2015a)

Farming families with houses on the land of the future irrigated area (and also sites for tracks, pumping stations, electric lines, etc.) will therefore be displaced and compensated for. The value of their assets (including fruit trees) must be assessed, and households must be compensated in kind by being allocated a permanent house, identical for everyone, of a value greater than that of their assets in almost all cases, built on a 1 ha plot. Families whose asset value exceeds that of the new house must receive an additional monetary compensation. ${ }^{10}$

What emerges indeed from the analysis of the preparatory phase is that, despite contradictions found in the project documents, displaced families will only be compensated with the "main" house and that they will have to rebuild outbuildings and equipment indispensable to daily life (kitchen, drying sheds, granaries, henhouses, enclosures, etc.) at their own cost, and they will have to plant new trees that will take a few years to bear fruit. We understand that the allocation of a new house has been conceived with a view to compensating for the destruction of assets, and at the same time for the work required to rebuild some of these assets, and the loss of income caused by the loss of fruit trees. It is therefore to be feared that the compensation measures provided for do not make it possible to compensate fully for the impact which the development of irrigated areas has on the monetary income and food security of directly impacted families. Displaced families are nonetheless supposed to receive an additional indemnity (i.e. a disturbance allowance) equivalent to $15 \%$ of the value of

\footnotetext{
${ }^{9}$ Village chief.

${ }^{10}$ The type of compensation, whether monetary or in kind, was discussed between the project stakeholders during the preparatory phase. Plot proportioning was adjusted in order to recreate a semi-dispersed settlement, if the family farmers of the three sites contested the idea of a nucleated settlement.
} 
their assets, in order to compensate for the inconvenience associated with the displacement. A budget is also provided for displacing their assets (removal).

\section{From sharing value to potentially transferring invested capital to villagers?}

The project documents mention that family farmers will benefit from a portion of the "receipts" of the capitalist farming company, in the form of rent paid by the latter (World Bank 2011). No clear distinction is however given between how the receipts should be shared and what would correspond to an appropriate payment of a rent for land "made available" by villagers. As regards sharing receipts, the project documents evoke indistinctly the "net profit" of the business, its "dividends" or its "income", without these values being explained in detail.

Finally, it is expected that, in the end, assets will be "ceded" to family farmers. But the terms to take over the capitalist company by family farmers - and where the funds to be mobilised will be coming from-are not specified in the project documents (IDSP/MAL/WB 2012).

As such there is still some vagueness about the delicate issue of value sharing, and that concerning what will become, in the end, of the investments is realised. The project documents we had access to remain silent on the amount of the rent to be paid by the capitalist farming company, on the price to be paid by farmers benefitting from the services supplied by the capitalist farming company, on the amount of the subsidies received by the capitalist farming company and family farmers, on the level of remuneration of the company that will manage the operation and maintenance of the irrigated areas (amount of the "water charges"), on the concrete methods of "sharing" the water and the charges, as well as on the conditions of reimbursement by the beneficiaries for the investment realised by the State. It is clear that the precisions brought in itinere, on these various points, will be decisive and will define the manner in which value added, created by running the irrigated scheme, will indeed be shared between the different stakeholders.

A preview of the actual implementation of the IDSP is shed below, with the example of the site of Mwomboshi, one of the first three sites chosen by the Zambian government to implement the IDSP (Fig. 2).

\section{From project documents to concrete implementation: the case of the site of Mwomboshi}

The implementation of the project which has been ongoing since 2012 on the site of Mwomboshi, in its investment phase, sheds a first light on the way some terms provided for by the documents of the IDSP are materialising. Apart from the construction of the water storage dam, which was completed in 2018, the implementation of the compensatory methods can already be observed on the ground.

\section{The area of Mwomboshi: Concrete elements and distinctive characteristics}

The area of Mwomboshi, situated $70 \mathrm{~km}$ north of Lusaka, is one of the three pilot sites where the IDSP is being implemented since 2012. 


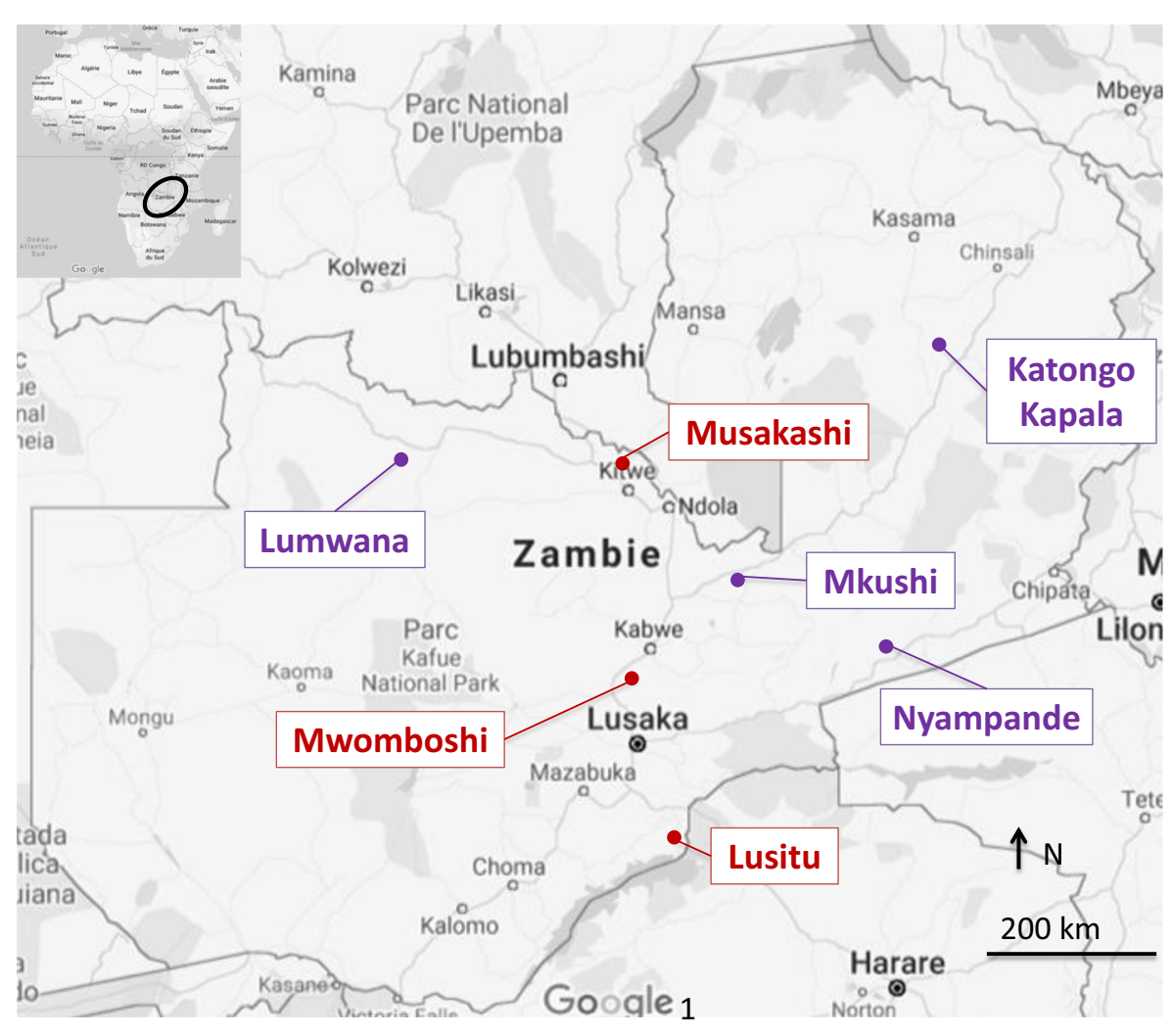

Fig. 2 Areas targeted by the IDSP in Zambia (in red, rural areas where the project is being implemented; in purple, rural areas pre-identified for a second phase of the project)

In Mwomboshi, the project consists of the construction of a water storage dam of 60 million $\mathrm{m}^{3}$ on the Mwomboshi River, intended for irrigation. The area directly impacted by the implementation of the project covers a surface area of around 5000 ha, of which around 2000 ha on the right bank of the Mwomboshi River is exploited by capitalist farmers already

Table 1 Land affected by the IDSP, on the left and right banks of the Mwomboshi River

\begin{tabular}{llc}
\hline & Left Bank & Right Bank \\
\hline Village Territory & 5107 & - \\
Land that will be flooded (ha) & 1006 & 748 \\
Land that can be irrigated (ha) & 1636 & 1175 \\
Tier 1 & 405 & - \\
Tier 2 & 295 & - \\
Tier 3 & 936 & - \\
Zone of resettlement & 398 & - \\
Remaining rain-fed land & 2067 & - \\
\hline
\end{tabular}

Source: authors, according to IDSP/MAL/WB 2015a 
present, and 3000 ha on the left bank is occupied by four villages (Malama, Toba, Hankwa and Kalimina) of family farmers (Figs. 3 and 4). In addition to this, around 2000 ha of rainfed land is indirectly affected by land redistribution. It is expected that 1754 ha of lowelevation land will be submerged and that 2811 ha will be irrigated (Table 1).

The Resettlement Action Plan (RAP), that began to be drafted in 2013 and was finally validated in 2017, mentions that the area of Mwomboshi is inhabited on the left bank by 3592 people, spread over 618 households, who constitute the potential beneficiaries of the project: the farming families of Mwomboshi, as such, will have access on average to 0.66 ha of irrigable land on "tier 1 " (to which on average 4 ha of rain-fed land or pastures are added). Moreover, the 295 ha of land on "tier 2" will be allocated to the 59 farming families ( 5 ha per family) with the "largest" agricultural surface areas. The RAP estimates that the total surface area being irrigated, prior to the project, is between 300 and 400 ha and that it is being cultivated by $65 \%$ of the households, i.e. on average 0.87 ha of irrigated land per family for around 400 families (to which on average between 7.6 and 7.8 ha of rain-fed land or pastures are added). While the cultivation area dedicated to the capitalist farmers, "tier 3 " and the corresponding irrigation pivot systems will be set up on the flat top of the interfluves; the area reserved for "tier 1 " is situated below, on the hillsides.

It is expected that 338 households will be displaced and that 398 ha will be dedicated to their resettlement.

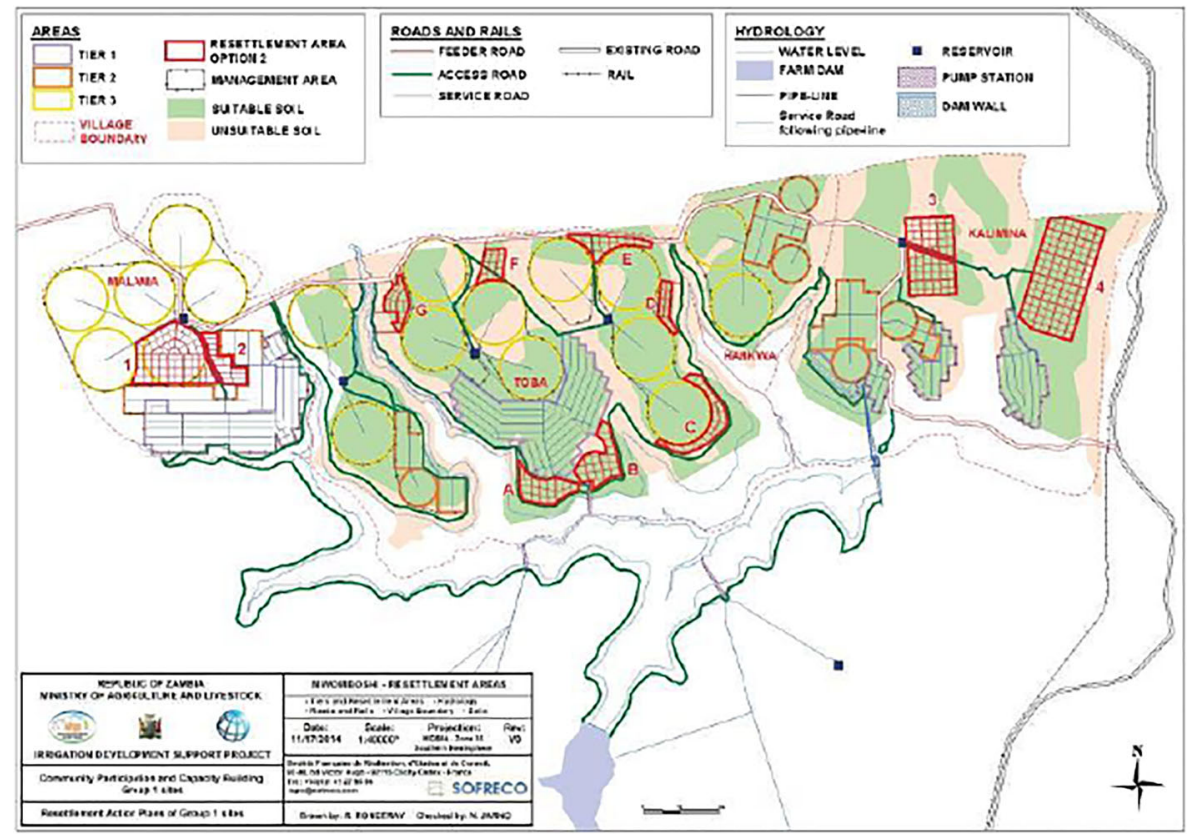

Fig. 3 The development plan of the IDSP, on the left bank (above) the Mwomboshi River. Source: IDSP/MAL/WB 2015a 


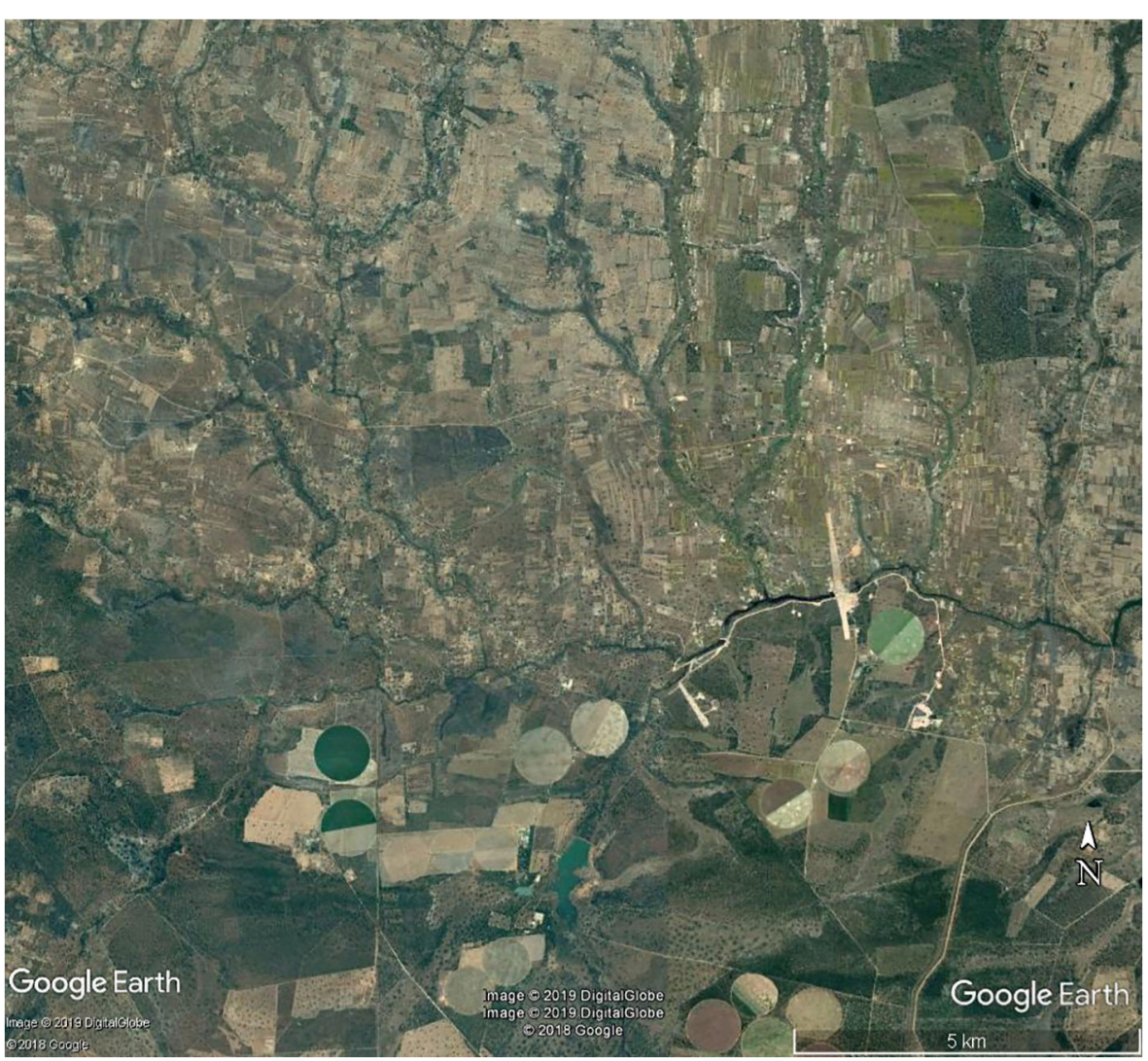

Fig. 4 Google Earth photo of the area impacted by the IDSP. The embankment of the dam under construction on the day the photo was taken (January 2018) can be seen in the centre-right of the photo; the large land parcels of the capitalist farmers of the right bank can be seen at the bottom of the photo. Source: authors according to Google Earth

The region of Mwomboshi, on the left bank, shows a population density which, in the Zambian context, is high with 50 to 100 inhabitants $/ \mathrm{km}^{2}$ depending on the villages, compared with a national average of a little more than 20 inhabitants $/ \mathrm{km}^{2}$. In this context and with the implementation of the project, competition to access land will be all the more intense: the loss of land submerged by the dam water and the mobilisation of almost 1000 ha for a capitalist farmer will leave little land to family farmers, whether for irrigated cultivation, rain-fed cultivation or cattle breeding. This satellite image (Fig. 4) makes it possible, in addition, to highlight the contrast between the land parcels of the right bank, occupied by a few large mechanised farms, the model of which is the inspiration for "tier 3" and the land of the left bank, developed by several hundreds of farms of a few hectares each. The latter nonetheless show a great diversity of situations, with land areas of various sizes: $17 \%$ of the families control $70 \%$ of the land according to the RAP; more than $80 \%$ of the families have access to less than 10 ha, i.e. 2.5 ha on average, whether or not combining irrigated crops (mainly tomatoes) and/or cattle breeding with rain-fed crops (mainly maize which is subsidised by the Zambian government, rotated with legumes), 
which constitute the basic food and economy of the households. Families with greater means, often those accessing large areas of land which allows them to develop cattle breeding, have at their disposal pairs of oxen and ploughs or even pumps for irrigation, while some families have no land (8\% of families according to the RAP).

Let us note that the capitalist farms settled on the right bank of the Mwomboshi River (Fig. 4), which today grow mostly wheat, soya and maize, will also have access to the dam water, thereby increasing the competition for water. In this specific case, they constitute "tier 4": irrigation water will be shared between the capitalist farms of the right bank, the capitalist farming companies that will cultivate "tier 3 " and the family farmers that will cultivate "tiers 1 and 2" on the left bank. The installation of irrigation infrastructure (pumps and canals) on the lands of "tier 4" is, however, not planned within the framework of the project and will be the responsibility of the capitalist farms. Their contribution to reimbursing the investment carried out by the State was under negotiation in 2014 (as was the case for the capitalist farming companies that will cultivate "tier 3").

\section{Investment, displacement and compensation}

\section{Land set aside longer than expected}

The visits and interviews we were able to conduct with several actors concerned by the project (local IDSP representative, members of the Community Land Trust bureau, village headmen and farmers) in the area of Mwomboshi, in December 2017, August 2018 and June 2019, made it possible for us to gather the following information ${ }^{11}$ : in December 2017 , 5 years after the start of the project, the State had converted the land ${ }^{12}$; the construction of the dam was under way; part of the future irrigable land was reserved and underwent clearing and levelling. The company responsible for the works had announced that the land would be mobilised less than a month before the beginning of the works and had scheduled it at the

\footnotetext{
${ }^{11}$ The aim of these visits and interviews was to follow up on the implementation of the project (work progress, displacement/resettlement/compensation of households, establishment/operating mode/activities of the Community Land Trust, status and redistribution of land), as well as its impact on farms (loss of land or even crops): 13 farmers were met, some during each visit, including the local IDSP representative, 8 members of the Community Land Trust and 1 village headman.

12 In December 2017, the local representative of the project mentioned "misunderstandings" on the part of the villagers and the need to hold "sensitisation meetings" in this regard: "Why and what is the benefice has been explained".

13 " [...] that movement should take place after harvest of rain-fed crops and before planting, so that village headman can secure access to sufficient accessible land for each displaced household before the move." (IDSP/MAL/WB 2015)

14 The local representative of the project mentioned in December 2017: "The farmers were suddenly informed to stop working on the land"; "Government cannot wait, they have a time frame schedule". The chairman of the Community Land Trust confirmed this "short notice" and mentioned: "We stood for the people".
} 
end of the dry season (November 2017), contrary to what had been planned in the RAP ${ }^{13}$, preventing farmers from anticipating the growing season (preparation/bedding or even clearing of plots outside the future irrigated area). Some farmers had even already prepared the soil and/or sowed on this land ${ }^{14}$. According to these farmers, the person in charge of the project, at the Zambian Ministry of Agriculture, promised them money for a then unknown amount, to compensate for the loss of production ${ }^{15}$. In December 2017, it was intended that the works would stop during the rainy season and resume in 2018, thereby immobilising land during one year at least. In August 2018, the works had been interrupted following the departure of one of the construction companies (only the dam was built; the pumps, the reservoirs and the pipe network were not installed), and a new year of land immobilisation was expected. In addition, those in charge of the project had requested from the farmers who were cultivating out of season, in the future submerged areas, that they free the land. In June 2019, the works had still not resumed, and it was anticipated that they be extended until the end of 2020, but the farmers re-appropriated and re-cultivated the land that had been reserved the previous year.

\section{Displacement, resettlement and compensation ${ }^{16}$}

The preparation of the RAP that provides the framework for the displacement of impacted families, their resettlement and indemnification in agreement with both national legislation and the expectations of the international donors (cf. "Compensation presented as exemplary and carried out before starting the works" section) constitutes a rate-limiting step in the implementation process of the project. Indeed, the RAP, considered as a precondition to starting the works, delayed the progress of the project: the document has been revised many times and more than three years went by between the submission of the first version in 2013 and its validation by the World Bank and the Zambian Ministry of Agriculture in 2017. We do not know the elements of the RAP that contributed to blocking the process, although according to some actors, it was partly attributable to the fact that the World Bank gave great significance to this document, which testifies to the intentions and the strictness of the institution on the issue of population displacement. This delay raises questions, however, on the difficulties encountered to agree on the "good" practices required within the framework of such projects, and the care with which the RAP was drafted must be linked to the sensitive issue of the way "benefitting" populations perceive the impact of this type of project and, from this angle, the way the funders of such projects are perceived.

\footnotetext{
${ }^{15}$ According to the local representative of the project, in August 2018, compensation commensurate with the expenses incurred by the farmers was indeed paid. Conversely, a member of the Community Land Trust mentioned the difficulties which farmers had faced during the growing season, following their displacement, for lack of sufficient land and compensation, which questioned the food security of the families concerned: "It is a challenge for people, they have small pieces of land and need to be helped by IDSP for food"; "Compensation are not given, concerns are not attended, we are worried and not very satisfied". One of the village headmen was also stressing these difficulties: "The only challenge we are meeting is the lack of enough land: what is remaining is too small for families."

${ }^{16}$ The elements mentioned in this paragraph are based on the professional experience of one of the authors of this article, between 2012 and 2014, within the framework of the IDSP, who worked for a consulting firm that was in charge of the Community Participation and Capacity Building component (CP\&CB) of the project and was contracted to that end by the Zambian Ministry of Agriculture between 2012 and 2017.
} 
According to the representatives of the World Bank and the Zambian Ministry of Agriculture, the villages concerned by the project were consulted. Some had given their agreement for implementing the project before its start in 2012, but some villages actually refused to be targeted by the project. As noted on several occasions during the preparatory phase, and on several sites of the IDSP, the reluctance or even opposition to the project by some villages or groups of individuals was neutralised rather than debated. In Mwomboshi in particular, some farmers refusing the idea of being displaced and ceding part of their land to an investor ${ }^{17}$ were "convinced" of the benefit of the project during three meetings involving representatives from the government as well as traditional and military authorities, in 2013 and 2014. Still in Mwomboshi, the information and consultation process with family farmers, the so-called beneficiaries of the project, did not end up in real negotiations between the family farmers, the Zambian State and the World Bank, where the farmers who were supposed to express their requests were reduced to silence through intimidation ${ }^{18}$. This reveals the difficulty of the public authorities and international organisations in taking into account the questions and claims of family farmers. This difficult consultation, as such, questions the practicality of such a project that yet advocates the joint development of family farming and capitalist farming, of adapting to the concrete reality and the needs of family farmers, but also to the specific characteristics of the type of farming they practice in their environment.

Considering the practices described above and according to the people encountered during the last visits, it seems to be generally admitted that "the adherence of all the villagers cannot be acquired" but that "the intention is not to force anyone to invest in the project", which amounts to the acceptance of promoting a project of which the cost is unavoidable (reduction of average cultivable surface area per farmer), but of which the "benefit" (access to irrigation under the conditions of the project) is not necessarily desired by the "beneficiaries". This, once it is put into perspective with the delays in drafting the RAP and the management of the negotiations (and even the conflicts) on the sites during the preparatory phase, highlights the contradictions between the principles of the IDSP that are described in the documents or are verbally defended and the implementation. It shows moreover two levels of political issues concerning displacements and their compensations: on the international scale, issues relating to funding and the image of development aid crystallised in this case through the drafting of the RAP that was delayed due to the demands of the World Bank as regards "good" practices; and also on the national scale: issues relating to the use, destination and impact of the funding, as indicated by the power games observed during the preparatory phase of the project, between government representatives and family farmers.

\footnotetext{
${ }^{17}$ In January 2014, during one of these meetings in the presence of around 50 villagers, men and women, the latter refused categorically the presence on their land of a capitalist farmer, irrespective of their state, and said that they had not been informed about the project from when it started: "According to what we know, [...] [our village] was not part of the project"; "We accept the dam, not tier 3"; "Here we do not need this project" (expressed in the local language and translated into English in the presence of one of the authors.)

${ }^{18}$ In June 2014, during a Public Disclosure Meeting held in Mwomboshi, the village representatives who had prepared a list of comments, demands and questions were told by a local authority representative: "Questions have already been answered; it's not time to answer questions, and not your problem. [...] [You] should be the one answering the questions, not asking them. [...] [We] are disappointed. [...] [This questions] are based on ignorance." (expressed in English in the presence of one of the authors, and reconstituted for this article from handwritten notes.).
} 
In December 2017, 186 houses had been built, and 32 families had been displaced. In August 2018, 28 additional families had been displaced, and 52 houses still had to be finalised. In June 2019, around twenty houses still had to be completed, no additional houses had been allocated, and the Community Land Trust in charge of their allocation had remained inactive for nine months, following its dissolution by the Ministry of Agriculture, a sign of disagreement and communication difficulties between these two entities $^{19}$. According to the farmers interviewed, those in charge of the project had taken care of the costs relating to the transport of assets of some displaced families. On the other hand, they had not financed the rebuilding of outside kitchens nor paid any disturbance allowance which although these were provided for in the project documents (supra) ${ }^{20}$.

\section{Loss of power by the village headmen}

As part of the implementation of the IDSP, in its investment phase, the village headmen of the left bank of the Mwomboshi River have lost their rights on the entire village territories, on the future irrigable land as well as on the remaining rain-fed land: indeed, while the project documents provided for the conversion of only the land developed for irrigation, all the village territories that came under customary land had become stateowned land. Village headmen conserve their authority and their role in managing social issues and conflicts inside villages but have lost their power and role in allocating land which became, from then on, the responsibility of the Community Land Trust whose members are elected by family farmers. Village headmen however still play an advisory role in reallocating non-irrigable land (e.g. spaces between future irrigation pivots) due to their knowledge and influence on the matter. According to members of the Community Land Trust encountered in Mwomboshi, this reallocation should take place on the basis of the "productive capacity" of farmers: in practice, and according to the farmers interviewed by us, sharing the remaining rain-fed land is difficult, and the need to allocate land to the young generations complicates the situation all the more. When the food security of some families was put at risk in 2018, these put in a request for food and financial aid to the Zambian Ministry of Agriculture, via the Community Land Trust: according to the farmers we met, aid was promised but not honoured (cf. note 15). This highlights the precariousness in which farmers who cede their land to the project find themselves and the reluctance of the others to share theirs in the face of uncertainty, as embodied by the project implementation.

\footnotetext{
${ }^{19}$ The Community Land Trust was re-established 9 months after it was dissolved, its members claiming to be responsible for ensuring that the RAP would indeed be adhered to during the implementation of the project in Mwomboshi. Trust members find that "things are not going according to the RAP", and that one must "ensure the RAP is followed" and "make sure people are given what was agreed".

${ }^{20}$ Those in charge of the project at the Ministry of Agriculture had justified this with the devaluation of the Kwacha since the beginning of the investment phase and, from this angle, by the increase in value (in Kwacha) of the houses being built. In December 2017, a woman farmer mentioned, for example, that the project had "paid someone who has an oxcart" to transport the wood that would be used to build a temporary external kitchen by her children, before building a permanent kitchen with bricks, once the rainy season has gone: "I did not pay anything, my children are doing it"; "After the rainy season, a big one with bricks will be built" (survey conducted in the local language interpreted into English).

${ }^{21}$ Two we know of, dating from 2014 and 2017, respectively.
} 


\section{A project little attractive for investors}

At this stage of the implementation of the IDSP (June 2019), no investors have been identified, and this despite several information and consultation workshops addressed to them ${ }^{21}$. As reported to us, the invitation to tender launched in 2017 yielded only one response from a capitalist farming company which was already present on one of the sites of the IDSP. This element highly questions the interest of investors for the project and, as such, their participation. The very principles of the IDSP and this type of project are consequently being questioned, as well as the possibility of creating synergies between capitalist and family farming. It is indeed to be feared that the functions attributed, in principle, to investors in this type of institutional set-up are likely to actually discourage capital holders. The financial profitability (expected by any business operating on the principles of a company) would, as a result, be too limited by the requested obligations: reimbursement of part of the investment, involvement in the management of the irrigation infrastructure, skills transfer and sector structuring. Moreover, the possibility of investing in agricultural land with less constraints, in Zambia or anywhere else in Africa, challenges this type of project. Will it then become necessary for the public authorities to make new concessions for capitalist entrepreneurs to show interest in the project? Will this be to the detriment of family farming development? Will the State take care of the functions attributed initially to capitalist farms? What will then remain of the PPP that was announced? In Mwomboshi, it was in fact expected, in December 2017, that while waiting for a potential investor prepared to invest in the project, that the operation of the irrigated area and support to family farmers would be ensured by the public authorities.

At this stage, and despite the information already at our disposal, it remains difficult to have a clear and precise idea of the way in which the project is going to function at cruising speed, once the investment phase has been achieved, and therefore it is difficult to anticipate its impact. A few thoughts, however, can be offered in the discussion.

\section{Complementarity or competition: towards a win-win farming model?}

The elements gathered in the previous pages illustrate the gap which can exist between the definition of the terms of the project and their implementation on the ground. They also offer information as to the way villagers were taken into account before being displaced and rehoused. The difficulties inherent to the brutal transition of the first years of the project, including in terms of lost harvests, have been highlighted. Reflecting on the projected project impact is also necessary however-and this is what we are proposing in this section - in the predicted impact of the project on affected populations, duly compensated and resettled on the edge of the irrigated area, when it reaches cruising speed, i.e. once the investment has been completed. We will also question a few elements of the project's possible impact in terms of economic analy$\mathrm{sis}^{22}$, from the point of view of the nation, i.e. for the whole of Zambia.

\footnotetext{
$\overline{{ }^{22} \text { As opposed to financial analysis }}$
} 
The project of the site of Mwomboshi, implemented within the framework of the IDSP, will have many and varied impacts on access to land and water as well as on markets. If we consider farms as sets of interdependent cultivating and/or breeding activities, associated with a specific combination of production factors linked to pedoclimatic and socioeconomic conditions, family farms will be impacted globally. It is therefore impossible to reduce the impact of the project to an impact on one crop or another being farmed by the "beneficiaries". While we could not pretend, within the framework of this article, to provide a complete provisional assessment procedure, it seems that we can already identify a few points of impact of the project, which will be assessed more precisely by the authors in future works.

\section{What is the provisional impact on "benefitting" families and the joint development of capitalist and family farming? Hypotheses and questions}

\section{From the point of view of the "beneficiaries": What impact on the production and income of family farms?}

The upcoming situation of the "benefiting" families (once the "cruise" situation is established, after the reservoir has been filled) remains uncertain. Which crops will they be able to grow on the irrigated plots of an average of 0.66 ha to which each family will be entitled? What will they farm on the 4 ha of rain-fed land that will be allocated to them on average? How will they manage a potential herd of cattle or goats, knowing that most of the bottom land which is available today will be submerged by the reservoir? Will the situation of impacted families improve, compared with the situation that would have prevailed if the project had not come into being?

The link between irrigation, increase in yield and increase in income is a strong assumption that has been used by project initiators to justify setting up the IDSP. They considered that the development of irrigation would enable family farmers to obtain agricultural incomes greater than those they would have obtained without developing irrigation. The declared objective was indeed to: "increase yields per hectare and value of diverse products marketed by smallholders benefitting from investments in irrigation in selected sites served by the project." (World Bank 2011).

However, this does not go without saying: indeed, in order to assess the situation, it is necessary to compare cultivating and breeding activities that would be combined by the same family farmer "benefitting" from the project (e.g. the beneficiary of a plot on "tier 1"), with the activities he could have been implementing if the project had not come into being. The technical and economic performance enabled by these combinations must be compared.

To this end, only considering the yield from irrigated cropping enabled within the framework of the project is insufficient to draw conclusions as to its impact on family farming. For the promoters of the project, it is yield which is defined as the objective and main indicator of success of the project. Yet, yield is not an economic indicator, and its link with agricultural income cannot be considered as direct. Indeed, yield has a direct impact on the economic result of the crop concerned, but it must be associated with mastering costs to enable an increase in the net value added and in the agricultural income (Cochet, 2015b). The cost to access irrigation water (still unknown at this stage of the project) as well as the cost of inputs (seeds, fertilizer and phytosanitary products) 
could turn out to be prohibitive considering the possible profit, thanks to the crops proposed within the framework of the project and in the Zambian context. In this sense, it is likely that less costly and therefore less risky crops are not going to be given up by family farmers, contrary to what is given as accepted by the authors of the project documents. It is therefore not very likely that irrigated crops will replace fully rain-fed crops.

Beyond the issue of the predicted impact of irrigation on yield and the range of possible crops, the Resettlement Action Plan (RAP) actually mentions explicitly that irrigation was already being practiced (prior to the project and definitely in the "without-project" scenario) by many farmers, as follows:

"The population depend almost entirely on agriculture and, at about US\$ 300 per ha, land productivity from cropping is quite high. Many households practice minor irrigation of vegetable crops in the dry season: the irrigated area may be between 300 and 400 ha. Livestock ownership is also important (over 800 cattle and 800 sheep and goats) and accounts for about $10 \%$ of net farm income." (IDSP/MAL/WB 2015a).

Between 300 and 400 ha would then have been already irrigated before setting up the project and would be in all probability in the "without-project" scenario: 300 to 400 ha for 618 families, i.e. around 0.5 to 0.65 ha/family on average, almost as much as what is expected to allocate to beneficiaries. It is in fact significant that the relative success of this small irrigation system, far less costly than the pressurised water irrigation proposed within the framework of the IDSP, is presented as a "risk" to the project:

"Another risk is the success of the present minor irrigation, which presents a cheaper and less risky (in terms of collective organization) alternative to the formal irrigation system being proposed by IDSP." (IDSP/MAL/WB 2015a)

The current success (prior to the project) of the small irrigation system would therefore threaten the successful implementation of the project, with future "beneficiaries" actually unable to find a reason to embark on the adventure of the IDSP.

In addition, the general decrease in surface areas accessible by each farmer because of the project (land submerged by the water storage dam, land allocated to "tier 3", i.e. almost $2000 \mathrm{ha}$ ) will put even more constraint on the cropping conditions and technical performances of families categorised in "tier 1".

As such, it is not certain that the project will lead, in practice, to a significant increase in the agricultural income of "benefitting" families. Furthermore, the IDSP will probably not have the same impact for all types of family farms, because the allocation of a similar irrigable surface area to all families registered in "tier 1", for example, does not mean that they will find themselves in similar conditions, as far as access to rain-fed land and means of production are concerned (cf. "From project documents to concrete implementation: the case of the site of Mwomboshi" section). 


\section{Capitalist farming and family farming, what real synergy?}

This new model of development intends to attract investors and makes their settlement a lever of development for small-scale family farming, the latter in the end coming to reinforce the actual farming business. In this regard, we can read in the Resettlement Action Plan (RAP):

"The experience and benefits of economies of scale of the commercial farm should be transferred to emergent and smallholder farmers through the provision of extension and marketing services. The services are acknowledged by smallholders by the use of some of their land by the commercial farm, the contribution smallholders will bring to the increased scale of farming activities on the irrigation scheme and as low-cost producers (and possibly out-growers) of the commercial enterprise." (IDSP/MAL/WB 2015a)

But the "attractive" conditions proposed to investors contribute above all to favouring the profitability of the capital invested: the idea is therefore to create conditions for privileged access to land, irrigation water and labour force, at relatively low cost in a tax environment which is also attractive (Cochet, 2015b). We then understand that, under these conditions, making capitalist companies and family farms "benefit" and "operate together" is not obvious insomuch as family farms are organised and function specifically to increase the return to family labour. Family incomes will also depend on the rent paid by the companies for the land made available, a rent which must be "attractive" for the investor.

Moreover, through the differentiated layout provided by the three "tiers" (cf. "Investment and water access methods" section), the project documents define "levels" of development and draw the agricultural development paths they seek to promote. The operating mode of the "commercial" farm is presented as the most "efficient" and as the horizon towards which family farming should tend. Yet, by fixing and limiting irrigation areas and techniques accessible to each "level", i.e. "small", "emergent" and "commercial", they fix on a long-term basis the operating modes of the environment. For family farmers who will access "tier 1", this raises questions regarding the possibilities underlying the evolution of techniques, cultivated areas and absorption of new generations of farmers. We cannot imagine how the 0.66 ha of irrigated land allocated on average to family farmers would enable them to evolve on the virtuous path of the "commercial" farm. Furthermore, the issue of selecting "tier 2" beneficiaries has still not been cleared up. Lastly, the allocation of irrigable land can lead to favouritism and could emphasise pre-existing inequalities.

\section{From the point of view of the nation: Cost and benefit of the project}

Beyond the issue of the impact of the project on the 680 families concerned, the main issue, still unresolved, seems to be that of its economic benefit from a national point of view. Apart from the high costs of the initial investment and compensation, additional costs relating to the implementation of this type of project must be taken into account. The unnecessary premature immobilisation of land in relation to the filling of the water storage dam and to the work involved in making the area operational (abandoning at 
least two seasons of rain-fed crops to allow bulldozers to work on future irrigable land and avoiding flooding risks on land that will later be submerged) reflects a shortfall in earnings for family farmers as well as for the nation, when we could have imagined that the works to be done (the installation of the buried piping in particular) would be interrupting the growing season only on a limited portion of the land).

Moreover, the fact that no investor replied to the invitation to tender that was launched for "tier 3", even though the tender offered immediate use, will have an important impact. What will become of these vast spaces, with the interfluves cleared at the top and intended to receive the irrigation pivots, if no candidate shows up? Will villagers have the opportunity to cultivate these vast spaces, at least during the rainy season (and with what land security?) while waiting for a taker? What impact will this operational delay have on the economic benefit of the project?

The fact that no capitalist company is putting in a bid is probably revealing another flaw in the development model advocated by the World Bank (cf. "A project little attractive for investors" section). While it was planned at the beginning, as is the case for all Public-Private Partnerships, that the "private sector" would take care of at least part of the initial investments (dam, network, pumping station, etc.), which was supposed to relieve accordingly the burden of debt supported by the Zambian state, it would seem that those responsible for the IDSP (and the World Bank itself) have given up on making the "private sector" take part in the initial investment, which shows that those that are often designated as investors are not ready to invest. Would they be ready then to take over a farm of the "tier 3" type, delivered ready for use (which would suppose, on their part, a much more moderate investment), and to assume the duties which the World Bank, in its win-win model, was allocating to the "private sector", i.e. (1) managing the irrigation infrastructure (maintaining the future irrigated area, collecting taxes from other beneficiaries, etc.), (2) transferring technology in favour of family farmers and (3) structuring agri-food systems? Or will it then become necessary for the public authorities to make new concessions for capitalist farms to show interest in the project? The fact that no candidate has come forward, for the moment, while participation in the initial investment is no longer required, augurs ill for the real participation of the "private sector" to the project. It is to be feared that the duties allocated in principle to the "private sector", in this type of institutional set up, will not really be taken care of. The logic of financial profitability (expected by any business operating on the principles of a capitalist company) is indeed little compatible with the "social" duties that the "private sector" is asked to fulfil. In the case of Mwomboshi, it has in fact already been envisaged that the public authorities (the Ministry of Agriculture and its technical services) will be ensuring the management tasks of the irrigated scheme, i.e. agricultural and advisory supervision with farmers from "tier 1" and, finally, "structuring the sectors" while waiting for the transferduring the hoped for but widely compromised expectation - of these tasks to "tier 3".

\section{Conclusion}

In a context of proliferation of land acquisitions and agricultural development projects presented as "win-win" for family and capitalist farmers, in Sub-Saharan Africa, the Zambian state is implementing a project financed by the World Bank, which relies on 
the idea of creating synergies between capitalist agriculture, considered as more "efficient", and family farming. Specifically, the initiators of the IDSP want to encourage capital holders to invest in undertakings that will participate financially in developing irrigation, in return for access to irrigable farming land. Family farmers that will cede the land will benefit from access to water at "a lesser cost" on part of the land, with an equipment deemed "adapted" to their supposed ability to invest, produce and sell. Farming companies will, in addition, supply paying training, input and market access services.

The comparative critical reading of the principles and terms of the project in its reference documents, made possible by monitoring the project since 2012, first with an operational then a scientific viewpoint, gives a more realistic idea of the philosophy underlying the implementation of the project. Analysis of these principles and terms makes it possible to highlight biases, contradictions and inaccuracies. The implementation of the IDSP, which is ongoing in three rural areas of Zambia, makes it possible to examine certain concrete elements, as well as the way these principles and terms are and will be applied in their local context. The first years of implementation highlight certain difficulties and raise questions. The accumulated delay, the fact that the demands of family farmers are taken into account with great difficulty, the immobilisation of future irrigable land and the incomplete compensation of displaced families during the investment phase in the area of Mwomboshi, all raise questions on the losses caused by the implementation of the project, from the point of view of family farmers as well as that of the nation. Finally, the fact that investors are not eager to invest in this type of partnership calls into question the very principles of the project.

Assessing more precisely the tangible provisional impact of the IDSP and, more generally, the win-win development model proposed by the World Bank through this type of project would require a deeper analysis at both regional and farm level, in order to understand the current dynamics and the ins and outs of the technical and economic performance of the farming practices. On this basis, the idea would then be to conduct a review in terms of systemic impact assessment (Delarue and Cochet 2013), by anticipating and comparing the evolutions of the farms with or without the implementation of the project. Consequently, this article only constitutes a first step in this assessment.

\section{Compliance with ethical standards}

Conflict of interest The authors declare that they have no conflict of interest.

\section{References}

Anseeuw, W., Burnod, P., Bourgoin, J., Maluleke, I., Niassy, S., (2016) Tendance des acquisitions foncières à grande échelle en Afrique, in : Pesche D., Losch B. Imbernon J. (Ed.), Une nouvelle ruralité émergente. Regards croisés sur les transformations rurales africaines. Atlas pour le programme Rural Futures du NEPAD, deuxième édition revue et augmentée, Montpellier, Cirad, NEPAD, 42-43.

Baker, J. L. (2000) Impact Evaluation - Evaluation de l'Impact des Projets de Développement sur la Pauvreté: Manuel à l'Attention des Praticiens. Washington DC: The World Bank, 196 p.

Blein, R., Ouattara, N., Teyssier, J., Désir, T., Fongang, G., (2017) Les pôles de croissance en Afrique de l'Ouest et du Centre : réalités, impacts, enjeux. ACF/CCFD-Terres solidaires/Oxfam France.

Borras, Saturnino, Jr., Franco, J. C., (2010) Towards a broader view of the politics of global land grab: Rethinking land issues, reframing resistance. ICAS Working Paper Series $\mathrm{N}^{\circ}$ 001, ICAS-LDPI-TNI, May 2010, 39 p. 
Borras, Saturnino Jr and Franco J. C., (2012) Global land grabbing and trajectories of agrarian change: A preliminary analysis, Journal of Agrarian Change, Vol. 12 No. 1, January 2012, pp. 34-59.

Bridier et al., (1980). Guide pratique d'analyse de projets : Evaluation et choix des projets d'investissement. Economica, Paris.

CAS, Centre d'Analyse Stratégique. (2010). Les cessions d'actifs agricoles dans les pays en développement: diagnostic et recommandations. Paris, France: La Documentation française.

Chu, J., (2012). A Blue Revolution for Zambia ? Large scale irrigation projects and land and water 'grabs'. In Allan, J. A., Keulertz, M., Sojamo, S., Warner, J. Handbook of Land and Water Grabs in Africa : Foreign direct investment and food and water security, (pp 207-220); London: Routledge.

Chu, J. M., (2013) Creating a Zambian breadbasket : 'Land grabs' and foreign investments in agriculture in Mkushi District, Zambia, The Land Deal Politics Initiatives, working paper, 27 p.

Chu, J., Young, K., Phiri, D., Zambia Land Alliance, (2015) Large-scale land acquisitions, displacement and resettlement in Zambia, policy brief 41, Plaas.

Cochet, H. (2012) The systeme agraire concept in francophone peasant studies. Geoforum, 43(1), 128-136.

Cochet, H. (2014) Accaparements fonciers et grands projets agricoles privés : exclusions paysannes ou création d'emploi ? In Les Exclusions Paysannes : quel impacts sur le marché international du travail ? Conférences \& Séminaires $N^{\circ}$ 12, décembre 2014 (pp. 53-63). Paris: AFD.

Cochet, H., (2015a) Comparative agriculture, Quae/springer, the Netherlands, 154 p. (first edition in French QUAE 2011).

Cochet, H. (2015b) Controverses sur l'efficacité économique des agricultures familiales: indicateurs pour une comparaison rigoureuse avec d'autres agricultures. Revue Tiers Monde, 1, 9-25.

Cochet, H. (2017). Capital-labour separation and unequal value added distribution: Repositioning land grabbing in the general movement of contemporary agricultural transformations. The Journal of Peasant Studies, 45(N7), 1410-1431. https://doi.org/10.1080/03066150.2017.1311866 .

Cochet, H., \& Devienne, S. (2006). Fonctionnement et performances économiques des systèmes de production agricole: une démarche à l'échelle régionale. Cahier Agricultures, 15(6), 578-583.

Cochet, H., Merlet, M., (2011). Land grabbing and share of the value added in agricultural processes. A new look at the distribution of land revenues. International Academic Conference 'Global Land Grabbing'6-8 April 2011, University of Sussex, Brighton, UK.

Cotula, L., Vermeulen, S., Leonard, R., Keeley, J., (2010). Land grab or development opportunity? Agricultural investment and international land deals in Africa. IIED, FAO and IFAD, London.

CFS (Committee on world food security), (2012). Voluntary guidelines on the responsible governance of tenure of land, fisheries and forests in the context of national food security, FAO, Rome, $47 \mathrm{p}$.

CSO (Central Statistical Office), (2014). Agriculture analytical report, Zambia 2010 census of population and housing, $52 \mathrm{p}$.

Daniel, S., Mittal, A. (2010). (Mis) investment in agriculture: The role of the international finance corporation in global land grabs. Oakland institute, $54 \mathrm{p}$.

Deininger K., Byerlee, D., Lindsay, J., Norton, A., Selod, H. \& Stickler, M. (2011). Rising global interest in farmland. Can it yield sustainable and equitable benefits? The International Bank for Reconstruction and Development / the World Bank. Washington, DC, USA, 214 p.

Deininger, K., \& Byerlee, D. (2012). The rise of large farms in land abundant countries: Do they have a future? World Development, Elsevier, 40(4), 701-714.

Delarue, J., \& Cochet, H. (2013). Systemic impact evaluation: A methodology for complex agricultural development projects. The case of a contract farming project in Guinea. European Journal of Development Research, 25(5), 778-796.

De Schutter, O. (2009). Large-scale land acquisitions and leases: A set of minimum principles and measures to address the human rights challenge. Report of the Special Rapporteur on the right to food, General Assembly, United Nations, 28 December 2009.

Dufumier, M. (1996). Les projets de développement agricole: manuel d'expertise. KARTHALA Editions, 360 p.

Fairhead, J., Melissa, L., \& Scoones, I. (2012). Green grabbing: A new appropriation of nature? The Journal of Peasant Studies, 39(2), 237-261.

FAO, (2009). From land grab to win-win - Seizing the opportunities of International Investments in Agriculture (FAO - Economic and Social Perspectives No. 4EN). Economic and Social Development Department of the Food and Agriculture Organization of the United Nations (FAO).

Fischer, G., Van Velthuzien, H.T., Shah, M.M. and Nachtergaele, F.O., (2002). Global agro-ecological assessment for agriculture in the 21st century: Methodology and results. IIASA/FAO Research Report, Laxenburg, Austria: RR-02-02. 
Gittinger, J. P. (1985). Economic analysis of agricultural projects (no. UNN76). Washington DC: The World Bank.

Herre, R. (2013). Fast track agribusiness expansion, land grabs and the role of European private and public financing in Zambia: A right to food perspective, Hands off the Land Alliance.

IDSP/MAL/WB. (2012). Community Participation and Capacity Building Provider Terms of Reference. (CP\&CB ToR).

IDSP/MAL/WB. (2015a) Mwomboshi site Resettlement Action Plans. (RAP) Resource document : moa.gov. $\mathrm{zm} /$ publications/.

IDSP/MAL/WB. (2015b). Mwomboshi site Environmental and Social Impact Assessments. (ESIA) Resource document : moa.gov.zm/publications/.

Laske, E., (2014). Dualisme agricole le long de la rivière de Mkushi, Province centrale, Zambie. Mémoire de fin d'étude, UFR Agriculture Comparée et Développement Agricole, AgroParisTech/AFD/IDSP, 71 p.

Losch, B., \& Fréguin-Gresh, S. (2013). Quelles agricultures face aux défis des transitions africaines ? Le small-scale versus large-scale en débat. Cahiers Agricultures, 22(1), 1-6. https://doi.org/10.1684 /agr.2012.0573 .

Ministry of Fisheries and Livestock, CSO (Central Statistic Office), (2019). The 2017/2018 Livestock and aquaculture census report, summary report, $42 \mathrm{p}$.

Nolte, K., (2013). Large-scale agricultural investments under poor land governance systems: Actors and institutions in the case of Zambia, GIGA working papers 221, GIGA German Institute of Global and Area Studies, $36 \mathrm{p}$.

Nolte, K., Subakanya, M., (2016). Relationship between large-scale agricultural investors and local communities: Lessons from two investments in Zambia, policy brief 79, Indaba Agricultural Policy Research Institute.

Nolte, K., Chamberlain, W., \& Giger, M. (2016). Land Matrix. International land deals for agriculture. Fresh insights from the land matrix: Analytical report II, Centre for Development and Environment (CDE), 68 p.

Oya, C. (2013). Methodological reflections on 'land grab' databases and the 'land grab' literature 'rush. The Journal of Peasant Studies · May 2013, 40, 503-520. https://doi.org/10.1080/03066150.2013.799465.

Pallière, A., \& Cochet, H. (2018). Large private agricultural projects and job creation: From discourse to reality. Case Study in Sella Limba, Sierra Leone, Land Use Policy, 76(2018), 422-431. https://doi. org/10.1016/j.landusepol.2018.02.017.

Purseigle F., Nguyen G. et Pierre Blanc P. (2017) (sous la direction de). Le nouveau capitalisme agricole. De la ferme à la firme, SciencesPo les Presses, $312 \mathrm{p}$.

Rangé, C., \& Cochet, H. (2018). Multi-usage familial et agriculture de firme sur les rives du lac Tchad : une comparaison des performances économiques. Natures, Sciences, Sociétés, 26(1), 33-48.

Songwe, V., Deininger K., (2009). Foreign Investment in Agricultural Production: Opportunities and challenges. Notes, Land Policy and Administration, Agriculture and Rural Development Notes, The World Bank, issue 45, Washington DC.

Technical Committee on Land Tenure and Development. [Merlet, M. Perdriault M., (AGTER)], (2010). Large-scale land appropriations. Analysis of the phenomenon and proposed guidelines for future action. AFD, MAEE, Paris. 53 p.

Technical Committee on Land Tenure and Development. (2017) Enjeux fonciers et modèles de développement sur les périmètres irrigués en Afrique de l'Ouest, les NOTES de SYNTHĖSE $\mathrm{N}^{\circ} 23$, juin 2017 (16 p).

UNCTAD. (2009). World investment report, transnational corporations. UNCTAD: Agricultural Production and Development.

World Bank. (2007). Development report 2008: Agriculture for development. Washington DC: The World Bank.

World Bank. (2011). IDSP Project Appraisal Document (PAD).

World Bank (2013). OP/BP, 4.12 Involuntary Resettlement. Operational manual.

Zoomers, A. (2013). A critical review of the policy debate on large-scale land acquisitions: fighting the symptoms or killing the heart. In: Sandra J.T.M. Evers, Caroline Seagle and Froukje Krijtenburg 2013: Africa for sale, Land and Society in Foreign Large-Scale Land Acquisitions in Africa, p. 55-77.

Publisher's note Springer Nature remains neutral with regard to jurisdictional claims in published maps and institutional affiliations. 